\title{
OBSTETRICAL RESEARCH IN THE NETHERLANDS IN THE NINETEENTH CENTURY
}

\author{
by
}

ANJA HIDDINGA*

\section{INTRODUCTION}

Nineteenth-century Germany is usually regarded as the place where scientific medicine in general, and physiology and clinical medicine in particular, were first established and developed most rapidly. ${ }^{1}$ Historians and sociologists of science have attempted to explain this phenomenon using either comparative or historical approaches, and focusing on such institutional factors as outstanding laboratory facilities, state involvement in the promotion of research, or the establishment of scientific careers. ${ }^{2}$ Other more socio-cultural explanatory factors include reaction against the extreme conceptions of Naturphilosophie, the political vigour of a young group of reformers, and the powerful promotion of a particular ideal of what medicine should be. ${ }^{3}$ For example, Ackerknecht has argued that

\begin{abstract}
They were reacting against the romantic past that had led German medicine into the dead end of vain speculation. But at the same time they refused to be satisfied with the type of medicine represented by the Paris and Vienna schools. They rejected what they called the 'ontological' approach of these schools; medicine should be concerned primarily with the study of disturbed function, not with the artificial construction of disease entities. The young Germans also objected
\end{abstract}

*Drs. A. Hiddinga, Wetenschapsdynamica, Universiteit van Amsterdam, Nieuwe Achtersgracht 166, 1018 WV Amsterdam, The Netherlands.

${ }^{1}$ Sometimes this point is stressed by reference to the relative number of scientific discoveries, or scientific productivity in nineteenth-century German medicine, as is done by J. Ben-David, 'Scientific productivity and academic organisation in nineteenth-century medicine', Amer. Sociol. Rev., 1960, 35: 828-843; A. Zloczower, Career opportunities and the growth of scientific discovery in nineteenth-century Germany, New York, Arno Press, 1981.

${ }^{2}$ Among the comparative studies on nineteenth-century German (medical) science those of Ben-David are the best known: Ben-David, op. cit., note 1 above; J. Ben-David, 'Academy, university, and research institute in the nineteenth and twentieth centuries', in K. Scheuch and H. V. Aleman (editors), Das Forschungsinstitut, Erlangen, IGW, 1978, pp. 27-47; See also: A. Flexner, Universities: American, English, German, Oxford University Press, 1930. Among the historical studies are: R. H. Shryock, The development of modern medicine, New York, Knopf, 1947; E. H. Ackerknecht, $A$ short history of medicine, Baltimore Md., and London, Johns Hopkins University Press, 1968; S. Flexner, The evolution and organisation of the university clinic, Oxford, Clarendon Press, 1939; A. Hirsch, Geschichte der medizinische Wissenschaften in Deutschland, (reprint of 1893 ed.); vol. 22 of Geschichte der Wissenschaften in Deutschland, New York, Johnson; Hildesheim, Olms, 1966; E. Mendelsohn, 'Revolution and reduction: the sociology of methodological and philosophical concerns in nineteenth-century biology', in Y. Elkana (editor), The interaction between science and philosophy, New York, Humanities Press, 1974, pp. 407-426; H. Eulner, Die Entwicklung der medizinischen Spezialfächer an den Universitäten des deutschen Sprachgebietes, Stuttgart, Enke 1970.

${ }^{3}$ Cf. E. Mendelsohn, 'The social construction of scientific knowledge', in E. Mendelsohn and P. Weingart (editors), The social production of scientific knowledge, Dordrecht, Reidel, 1977, pp. 3-27. 


\section{Anja Hiddinga}

to the purely anatomical approach of Paris and Vienna. They maintained that what was observed on the autopsy table was only the end result of a pathological process, not the process itself. This process could be understood only through a study of disturbed function. Thus "pathological physiology" became the slogan of the new school. ${ }^{4}$

Some authors go further and relate the conceptual development of German (Prussian) biomedicine to the campaigns for social change in which many of these reformers participated. ${ }^{5}$

The historiography of medicine still bears many of the hallmarks of its "heroic" past. Thus Holland, a neighbouring country that traditionally maintained close relations with Germany, has received little attention either in comparative or in historical studies. One reason for this neglect might be the problem of language, seemingly a major inhibition for non-Dutch researchers; but a second and equally important difficulty involves the paucity of historical studies of nineteenth-century Dutch science. One might conclude that there simply was no Dutch science of any importance, and that therefore there is no good reason, beyond mere curiosity or perhaps patriotism, to pursue historical investigations. Well-known facts, however, do not support this conclusion. Outstanding Dutch researchers achieved major results in the last decades of the nineteenth century, especially in the physical sciences. It seems reasonable to expect that scientists with established international reputations, such as Lorentz, Van't Hoff, Van der Waals, De Vries, and Kamerling Onnes, emerged from and in turn encouraged a climate favourable to the pursuit of scientific knowledge. Given the close links with Germany, and given the supposition that there did exist some research activity in Holland in the nineteenth century, at least in the physical sciences, it seems worthwhile to investigate the development of medical science in Holland. How, then, was the new medicine received there, and how was it shaped by the social circumstances it encountered?

In undertaking this enterprise, I have tried to look not only at organizational aspects and institutional changes, but also at changes in the ideal of medical sciences as it was interpreted or understood in Holland. This study is based on the assumption that cognitive and social process are intimately linked and that one cannot be understood without the other. The available literature on clinical medicine in Germany will be used here as a heuristic device, and no thorough comparison of the Dutch and German situation will be attempted. Such an enterprise would require more quantitative data and information about the social and political setting of science in Holland than is currently available. Thus, the available knowledge about science in Germany will be used as a guide in the search for possible explanations. In order to make the analysis as precise as possible, I shall focus on the development of one specific clinical discipline, obstetrics, one of the oldest medical specialties, whose early establishment and development as a separate discipline within the biomedical sciences provides an opportunity for studying cognitive development in relation to radical changes in the intellectual climate of nineteenth-century society.

\footnotetext{
${ }^{4}$ Ackerknecht, op. cit., note 2 above, p. 171.

5 P. Weindling, 'Theories of the cell state in Imperial Germany', in C. Webster (editor), Biology, medicine and society 1840-1940, Cambridge University Press, 1981, pp. 99-157.
} 


\section{Obstetrical research in The Netherlands}

The paper will focus first on the organizational aspects of the emergence of medical science in Holland in general, especially on the reorganization of Dutch medical legislation. We shall find a group of doctors voicing professional demands, and organizing themselves to promote their ideal of clinical science. A discussion of the particular form and direction of this ideal in Holland, and of the research effort it gave rise to, will be followed by a closer study of the case of obstetrics, in which, as I shall try to demonstrate, no research tradition comparable to that established in Germany developed in The Netherlands. Finally, I shall attempt to explain this phenomenon by examining the conditions of clinical practice in obstetrics, its institutional setting, and its intellectual context.

\section{The Reorganization of Dutch Medical Legislation}

The very complicated and lengthy development of medical legislation in Holland in the nineteenth century can only be broadly outlined here. Much of it needs to be understood in the context of the turbulent social and political changes that took place in Dutch society. By the end of the century, the socio-political situation in the relatively young Dutch state bore little resemblance to that at the beginning of the century. ${ }^{6}$ Although these processes are of major importance for understanding the development of The Netherlands,they can here be sketched in only as a background against which the struggles for the legal organization of medical education and medical authority should be understood.

The first-law regulating the issuing of medical licences was passed in 1818. It reinforced an already existing division between graduates (university-trained doctors with a largely theoretical education) and non-graduates trained through apprenticeship. In order to graduate, university-trained doctors were required to write a dissertation in one of three disciplines: internal medicine, obstetrics, or surgery. This gave them the right to practise in only that one area. The extent to which they could combine more than one of these practices was limited, even if they had graduated in all three.

After 1818, the non-graduate doctors (city healing-masters, country healingmasters, male and female midwives, surgeons, tooth-masters, etc.) were required to pass an examination before a local departmental or provincial committee, composed of graduate doctors. The issuing of licences to non-graduate doctors differed widely, but the most evident distinction was that between country and city doctors. Usually, the non-graduate doctors acquired the skills and knowledge needed to pass the examination via an apprenticeship in an existing practice or by attending a private school. Clinical schools were established by the state in 1823 in order to improve the clinical training of the non-graduate doctors. ${ }^{7}$ In a legal arrangement of 1830 , however, the requirement of school attendance prior to examinations was dropped again. Following this change, anyone could attempt to pass the examinations, however or wherever he might have acquired his knowledge and skill.

\footnotetext{
${ }^{6}$ For a thorough political-economic history of Holland and Belgium see E. H. Kossman, The Low Countries 1780-1940, Oxford, Clarendon Press, 1978.

${ }^{7}$ D. Cannegieter, Honderdvijftig Jaar Gezondheidswet, Assen, Van Gorcum, 1954.
} 


\section{Anja Hiddinga}

The laws of 1818 and 1823 are the two most important laws regulating medical practice in the first half of the century: they were subsequently altered slightly and extended. However, the measures proposed could hardly be implemented because of the lack of proper institutions and the declining interest of committee members. Moreover, adherence to the laws could not be monitored sufficiently. ${ }^{8}$

In general, this period of Dutch history is characterized by historians as one of uncertainty about the future of the new state after the French had ceased occupation in 1813 , resulting in "the stagnating and placid society of the $1820 \mathrm{~s}$ ". 9 The revolution of the Belgians in 1830 and their subsequent separation from The Netherlands created more political instability, but at the same time made room for a sense of national identity. "Only after 1840 did the Dutch, under constantly deteriorating economic circumstances, start trying to develop their political system." 10

Repeated attempts on the part of the government to bring order into the variety of licences available in the medical occupations during the first decades of the nineteenth century have to be seen in this light.

Medical groups, faced with a sequence of changes in laws regulating education and licensing, were unable to develop a commmon perspective. Because of the limitations on their practice, the graduate doctores medicinae, doctores artis obstetricae, and doctores chirurgiae felt disadvantaged in comparison with the non-graduate doctors, even though the non-graduates had to call on them for help in special cases (mainly operations). Given the considerable growth in the number of doctors, especially non-graduates, this situation led in the $1830 \mathrm{~s}$ and ' 40 s to a growing polarization and competition between graduates and non-graduates. ${ }^{11}$ Finally, in order to regulate the medical profession, a state committee without representatives of the non-graduate doctors was installed in 1848 to advise the government.

The graduate doctors did not constitute a homogeneous group. Conservative as well as progressive sentiments were expressed, but the proponents of the more modern view were the most outspoken. We shall examine later the content and character of these ideas. Three professors on the committee belonged to the more conservative group of doctors and sought only a few minor changes in the 1818 law. Although other committee members from the group of progressive doctors argued that a radical revision of medical legislation was necessary, and although they were supported by prominent professors (all from Amsterdam and Utrecht), the ministerial draft of legislation based on this report was rejected by Parliament. One committee member

${ }^{8}$ Cf. J. A. Verdoorn, Het Amsterdamse Gezondheidswezen in de Negentiende Eeuw, [reprint], Nijmegen, SUN, 1981, pp. 85-95; C. C. Delprat, 'Het ontstann der Nederlandse Maatschappij der Geneeskunst en haar rol bij de herziening der geneeskundige staatsregeling van 1818', Gedenkboek der Nederlandse Maatschappij tot Bevordering der Geneeskunst, Amsterdam, 8 July 1924, pp. 19-110; J. Goudsmit, Anderhalve Eeuw Dokteren aan de Arts, Amsterdam, SUA, 1978, ch. 1.

${ }_{9}$ Kossman, op. cit., note 6 above, p. 137.

10 Ibid., p. 179.

${ }^{11}$ For a fine article on the growing polarization between graduate and non-graduate doctors, and the final decline of the latter, see M. J. van Lieburg, 'De Tweede Geneeskundige Stand', Tijdschrift voor Geschiedenis, 1983, 96: 433-453. Van Lieburg gives the following figures: the number of graduate doctors rose from 637 in 1820 to 841 in 1842, the number of non-graduate doctors practising in the city from 298 in 1820 to 451 in 1842, and the number of non-graduate doctors practising in the country from 783 in 1820 to 1002 in 1842. 


\section{Obstetrical research in The Netherlands}

from the group of "modern" doctors then called for all medical professionals to join forces. "How can we still remain active, now that the government does not want to do anything?"12 The answer was the establishment of the Dutch Association for the Promotion of Medicine (NMG).

The NMG was the first professional organization of doctors in Holland following the abolition of the guilds at the end of the eighteenth century. Its ideal was to establish medicine on a thorough scientific basis, and it demanded uniform standards in university education and in medical licensing. ${ }^{13}$ This demand for one and the same licence for all doctors made the NMG officially an organization representing both graduates and non-graduates. In reality, though, the interests of these two groups were far from identical, a division reflected in the divergent viewpoints of the several local sections of the NMG. The founders of the organization, mostly reform-minded professors in Amsterdam and Utrecht with connexions to higher governmental circles through their membership of state committees on the reorganization of medical law, functioned as a pressure group ${ }^{14}$ within the $\mathrm{NMG}$, and primarily served the interests of the graduate doctors. The scientific character of medicine was one of the arguments used by the NMG to stress the need for university-educated doctors. Although the progressive doctors' critique of the lamentable state of the organization of health care in Holland may have been correct, ${ }^{15}$ their demands for change can also be interpreted as a strategy on the part of some graduates to assert their expertise in questions of health and disease. This point was made with particular eloquence by the aggressive Prof. Mulder from Utrecht, a member of the NMG: "You, my gentlemen, are the experts here; your judgement, honestly and precisely expressed after thorough and extensive investigation, has to be elevated to law, and the States-General cannot but follow your judgement, because they are the non-experts in medicine; they are there for the sake of unity, not to pass a judgement on things of which they have no knowledge." 16

This stress on education, the claim to expert knowledge, and demands for controls over education and licensing are among the elements of the process of professionalization that took place in Dutch medicine. ${ }^{17}$ The strategic demand for a university education as the best form of medical training was clearly in the interest of the graduates. In this respect, this group profited from the persistent power of the

12 Quoted by C. E. Daniels, 'Dr. P. J. Heye', NTG, 1909, p. 738.

13 Cf. Algemeen Rapport uitgebracht door de Nederlandse Maatschappij tot Bevordering der Geneeskunst, Amsterdam 1848.

${ }_{14}$ Cf. Van Lieburg, op. cit., note 11 above p. 448.

15 For descriptions of the general state of health and health care in Holland, see: W. A. Romein, Welvaart en Gezondheid, Amsterdam, Algemeen Ziekenfonds Ziekenzorg, 1955; Kossman, op. cit., note 6 above; H. Brugmans (editor), Geschiedenis van Nederland, 8 vols., Amsterdam, Uitgeverij Joost van den Vondel, 1935-1938, vols. 7 and 8 by L. G. J. Verberne; Verdoorn, op. cit., note 8 above; J. and A. Romein, De Lage Landen bij de Zee, Amsterdam, Querido, 1976.

${ }^{16}$ Statement made in the opening lecture of the second General Meeting of the NMG in Utrecht, published in NTG 1880 , p. 127.

${ }^{17}$ Many writers have indicated these factors as important characteristics of the process of professionalization, see e.g. E. Friedson, Profession of medicine. A study of the sociology of applied knowledge, New York, Dodd, Mead, 1970; A. L. Mok, Beroepen in Aktie. Bijdragen tot een Beroepensociologie, Meppel, Boom, 1973; T. Johnson, Professions and power, London, Macmillan, 1972. 
radical young progressives in their ranks, who were convinced that only scientific, rational knowledge could provide a valid foundation for all parts of medicine. Their arguments referred not only to the use of rational methods, quantitative data, careful observation, use of apparatus, etc., but also implied a view of medicine as a unity of related subjects, not a collection of specialties. In their view, the basic science of medicine was physiology, which elucidated the general principles fundamental to the functioning of all life just as Newtonian mechanics had become the basis of physics by elucidating the principles of the material world. The general laws of physiology, applicable to all life, united the medical sciences. I shall discuss this changed conception of what medicine should be in the next section; it is important to mention here that the changing conception was reflected in the titles and content of contemporary journals, and in the take-over of their editorial boards by reformminded doctors. Several new periodicals were also launched during the $1840 \mathrm{~s} .{ }^{18} \mathrm{In}$ 1857 , the NMG brought about a fusion of all the existing medical journals that shared their conception of scientific medicine, and the newly created Dutch Journal of Medicine (Nederlands Tijdschrift voor Geneeskunde) became the official organ of the NMG. In 1865, in the face of continuing demands from the board of the NMG ${ }^{19}$ the authority of the medical professions was finally regulated. All medical students would be required henceforth to pass a state examination consisting of theoretical and clinical parts (the latter being new), which conveyed the right to the title of Arts (doctor) and authority to practise in all fields of medicine. At the same time, the requirement of writing a dissertation to acquire a licence to practise was allowed to lapse. All clinical schools were abolished, and though it was theoretically possible to take the examination without university training, in practice, the abolition of clinical schools signalled the final victory of the graduates. The "requirements" for the examination could be met only by attending the universities, or the Atheneum Illustre in Amsterdam, which was not officially a university. Students of the Atheneum could not pass the final examination in their own institute but had to take a state examination. The Amsterdam professors were so well represented on the state examination committee though, that the Atheneum had certainly, if reluctantly, to be taken seriously as a place for educating doctors by the three existing universities (Groningen, Utrecht, Leiden). In 1876, under the unrelenting pressure of the powerful modernizers of medicine within the NMG ${ }^{20}$ the Atheneum Illustre was elevated to the University of Amsterdam. Medical education therefore became completely localized in the universities and the demands of the reformers were to a large extent met. This was a development strongly resisted by the long-established, conservative university of Leiden. ${ }^{21}$ The NMG board, however, consisted of representatives of the progressive group of doctors, of whom the Amsterdamers were an important part.

So, from 1876 onwards, the universities were obliged to offer clinical education to a large number of students, and professors were appointed in all clinical subjects. Slowly,

${ }^{18}$ C. C. Delprat, 'De Geschiedenis der Nederlandse Tijdschriften', NTG, 1926, 1: 3ff.

${ }^{19}$ Handeligen der Nederlandse Maatschappij tot Bevordering der Geneeskunst, 1859-1864.

${ }^{20}$ Ibid., 1876-1879; Gedenkboek der Nederlandse Maatschappij tot Bevordering der Geneeskunst, Amsterdam, 8 July 1924.

${ }^{21}$ D. de. Moulin et al., Vier Eeuwen Amsterdams Binnengasthuis, Wormer, Inmerc, 1981; Verdoorn, op. cit., note 8 above. 


\section{Obstetrical research in The Netherlands}

the practices of the non-graduates were filled by graduates. The final regulation of medical authority and education meant not only a victory of the graduates over the non-graduates, but also the victory of a "modern" approach towards medicine over a conservative one. The idea of clinical medicine had become firmly established in Holland by the last quarter of the nineteenth century.

\section{Clinical Medicine}

The origin of the modern concept of medicine, in which clinical medical practice plays such an important part, must be sought primarily in the flourishing medical centres of the first half of the century, and especially in Paris. Here, the combination of physical examination and autopsies was advocated as the only way to valid knowledge of disease. Pathological anatomy and physical diagnostic methods like auscultation, percussion, and measurement of body temperature, became central to medical training. ${ }^{22}$ This approach to medicine, in which the clinic was vitally important, soon took root in other European cities with big hospitals. Vienna, in particular, became an outstanding medical centre, and, besides the great French authorities like Bichat and Laennec, Skoda and Rokitansky acquired great authority in European medicine. Many Dutch doctors travelled to both Paris and Vienna after having finished their studies. $^{23}$

The influence of these schools can be traced, for example, in the career of Jan van Geuns, who was appointed by the Amsterdam City Council in 1847 as a professor of forensic medicine and general pathology in the Atheneum Illustre. Previously, professors there were expected to provide only a theoretical education in medicine. Students had almost no opportunity to apply their knowledge in actual practice during their studies. The clinical school in Amsterdam, which did possess a reasonable hospital, educated the non-academic doctors and was forbidden ground for the Atheneum professors. Van Geuns, however, agreed to accept his professorship only on condition that "I be given the opportunity to relate the study of pathology to observations at the sickbed, and this not only for reasons of personal practice, but especially for the sake of education and science". ${ }^{24}$ In fact, he found support in the reports of foreign visitors who had questioned the absence of links between medical education and hospitals in Holland. ${ }^{25}$. After an initial refusal, the city authorities and the board of governors of the clinical school hospital finally accepted his condition. In his inaugural lecture he further elaborated the relation between medical theory and practice:

... as soon as the fruits of scientific investigation are taken up by practical medicine, as soon as the development and course of the investigations of science exercise their influences on the art, so that the eye is directed in its observations and the acts of the doctor are governed by theory, the separation between theory and practice in the further development of science becomes dangerous. ${ }^{26}$

22 Ackerknecht, op. cit., note 2 above.

${ }^{23}$ H. T. Deelman, De Geneeskunst voor Honderd Jaren, ontleend aan het dagboek-reisjournaal van J. C. Broers, P. J. I. de Frémery en C. B. Tilanus, Haarlem, 1920.

24 J. van Geuns, De Geneeskunde als Zelfstandige Wetenschap, inaugural lecture held in Amsterdam, 28 January 1847, p. 26.

${ }^{25}$ Cf., e.g., E. Meiszer, Bemerkungen aus dem Taschenbuche eines Arztes während einer Reise von Odessa durch ein Theil von Deutschland, Holland, England und Schotland, [n.p.] 1818.

${ }^{26}$ Van Geuns, op. cit., note 24 above, p. 2. 


\section{Anja Hiddinga}

... The fusion [of theory and practice] has to be reestablished with new force by science, which must provide us with the objectives of our searching; it must allow us to recognize distinctly the direction that will lead us to those objectives. The word in which this all comes together is: Medicine has to be an independent natural science. ${ }^{27}$

Van Geuns put all his energy into attempts to create the scientific medicine he sketched in his inaugural lecture. It was he who introduced auscultation and percussion, the so-called physical methods of clinical investigation, and the thermometer into the clinic.

In the second half of the century, however, developments in Germany became the focus of attention of the medical world. Young German doctors were reacting strongly against the speculative theories in the romantic tradition, most prevalent in Germany at the beginning of the nineteenth century. They built on the accomplishments of the Paris and Vienna schools, but objected to their purely anatomical approach. They put much more emphasis on the study of the process of the disease than on its locally visible end-products. Disease, according to this view, had to be seen as a disturbance of the basic body functions, and for these to be known, like physics and chemistry, medicine had to search for the general laws and principles that regulated the process in the body. Physiology, consequently, was vitally important. In France, Claude Bernard had to fight the powerful clinicians who were not prepared to give up their strongly hospital-based medicine for a laboratory-based physiology. Germany, where the new role of full-time professional scientist developed, provided a more fertile ground for this new conception of medicine. ${ }^{28}$

The new views on clinical medicine, in which physiological pathology had become the most important field of study, soon had influence all over Europe and the USA. In Holland, this can be traced, for example, in Van Geuns' attempts to establish a laboratory. In 1855, thanks to his efforts, a "physiological-pathological laboratory" was set up in an old kitchen of the clinical school, and in 1858, he was able to persuade the City Council to provide the money for an extra professorship in physiology, in order to assure education in that part of the subject "that rests more immediately on chemical and physical experiments".29

In Utrecht, Donders, who already enjoyed an international reputation as a physiologist, was granted a professorship in this subject in 1852 . He was also one of the representatives of the "new medicine", and was active in the NMG. He too was convinced of the need for a strong link between practice and theory, and he combined his experimental research involving the physiology of sight in animals with his practice as an ophthalmologist in an Utrecht eye-clinic for the poor, especially created for him with private money. ${ }^{30}$ Except for Donders' laboratory and clinic, the medical faculty of Utrecht University was poorly equipped and had a very small hospital. The same was true for Groningen, where the university was, in fact, constantly in danger of being

${ }^{27}$ Ibid., p. 3.

${ }^{28}$ Ackerknecht, op. cit., note 2 above; G. L. Geison, 'Divided we stand: physiologists and clinicians in the American context', in J. Vogel and C. E. Rosenberg (editors), The therapeutic revolution, University of Pennsylvania Press, 1979, pp. 67-91.

${ }^{29}$ Minutes of the meeting of the clinical school professors, 21 June 1858, Amsterdam, Municipal Archive, File 30 nr. 25.

${ }^{30}$ J. P. Fockema Andrea et al., De Utrechtse Universiteit 1815-1936, Utrecht, Oosthoek, 1936, vol 2, pp. 215-281: 'De Medische Faculteit'. 


\section{Obstetrical research in The Netherlands}

closed down because of the lack of students; ${ }^{31}$ and for Leiden, where discussions with the city authorities about the building of a proper hospital went on for decades. ${ }^{32}$

In the new German conception of clinical medicine, ontological concepts of disease were rejected: illness had to be understood as a disturbance or deregulation of the basic processes in the body. Virchow, the promoter of clinical science in Germany, defined illness as follows: "Alle Krankheiten lassen sich zuletzt auf aktive oder passive Störungen grösserer oder kleinerer Summen der vitalen Elemente zurückführen, deren Leistungsfähigkeit je nach den Zuständen ihren molekulären Zusammensetzung sich ändert, also von physikalischen und chemischen Veränderungen ihres Inhaltes abhängig ist." 33 Virchow's definition makes clear how important the physical and chemical processes in the body were considered to be. Physiology, looked upon as a "model" discipline resembling the natural sciences, was to unravel the basic process of life and by experiment establish the laws according to which they worked. Virchow possessed great authority among the Dutch progressive doctors. As Lehmann, a reader in obstetrics in the Amsterdam clinical school and one of the founders of the NMG, stated in 1863: "The brilliant Virchow, who as a result of his investigations and experiments has expressed and introduced as the now predominant principle in science this great thought about the healthy and diseased state of life, i.e., that phenomena of disease are phenomena of life, in principle just as lawlike and necessary as the expressions of the whole body." ${ }^{34} \mathrm{He}$ stressed the status of clinical science in relation to physiology by emphasizing the relation between medical knowledge and clinical practice:

Physiology may be the basis for medicine, but it does not always follow the right road, and results gathered outside the body have often been applied too lightheartedly to phenomena in the living organism. ... Great physiologists, moreover, are seldom good doctors at the sickbed, and no wonder, since where the clinic has disappeared and only the laboratory governs, no medicine can flourish rightly. ... Not everything may be offered to the cult of facts, under the flag of the auxiliary sciences it [rational therapy] has to be found, based on clinical experience, supported by experiment and induction, it has to be applied and to be controlled by statistics. ... 35

The emphasis on physiology as a basic science and on clinical practice was of vital importance, for medical science went hand in hand with the strong conviction that man was actually capable of influencing physiological processes by controlling the physical and chemical factors: "The organic processes of the human organism are no less subject to our power than those of organic nature. Just as one can force the soil to produce one harvest or another when one knows the conditions of its fertility and the means that influence it, so it will also be possible to control the functions of some organs, to limit the pathological processes in their course and to stop them." 36

The conditions under which the idea of clinical science arose in Holland show some similarities to those in Germany, but they also show some important differences. In the

${ }_{31}$ C. E. Visser (editor), Universitas Groningana, MCMXIV-MCMLXIV, Groningen, J. B. Wolters, 1964.

${ }^{32}$ P. H. Simon Thomas, Het Onderwijs in de Verloskunde aan de Leidse Hoogeschool, Leiden, S. C. van Doesburgh, 1909.

${ }_{33}$ Quoted by K. E. Rothschuh, Konzepte der Medizin, Stuttgart, Hippokrates Verlag, 1978, p. 8.

${ }^{34}$ L. Lehmann, Het Tegenwoordige Standpunt der Geneeskunde met Hare Licht en Schaduwzijde, Amsterdam, 1870, p. 4.

35 Ibid., p. 13.

${ }^{36}$ Ibid., p. 8. 


\title{
Anja Hiddinga
}

first place, both in Germany and in Holland the members of the group of progressive doctors were young, and one can speak in terms of a generational conflict. ${ }^{37,38}$ However, the traditional views against which the modernizers reacted were different in the two countries. While romanticism was a strongly established tradition in Germany, in Holland this had been taken up in much less extreme forms, so that some historians speak of eclecticism instead of romanticism. ${ }^{39}$ Moreover, although the social and political instability of the 1840 s and ' 50 s was great in both countries, the Dutch progressives did not engage in political action to the same extent as the Germans. ${ }^{40}$ The conscious German link between reform in science and medicine and reform in society was not present in Holland in the same form. The objective of the Dutch reformers was to assert their authority on questions of health, education, and the licensing of doctors, and to take this authority over from the state. This was the content of their political struggle and the basis for the establishment of the NMG. Initially, the government regarded the establishment and the articles of the association as an attempt to resist the legal authority of the state. But such "misunderstandings" were soon clarified:

\begin{abstract}
since the breeding of revolutionary principles is something never thought of in our Association. Moreover, nothing has been further removed from our Association, ... than the pursuit of political influence. On the contrary, one of its greatest advantages is that it stands outside all politics, that no political orientations exist for it. It only strives for improvements it is qualified to judge and that are of equal importance for all parties, for all directions. ${ }^{41}$
\end{abstract}

Indeed, although some of the reformers united in the NMG did engage in more political and social debates, the fact that the group which promoted the ideal of scientific medicine had organized the NMG primarily as a professional organization gave the ideal of reform in medicine, as it was picked up from Germany, a particular colouring, one linked to professional interests.

\section{The Ideal of Clinical Sciences in Obstetrics}

Having sketched the institutional and ideological changes in general terms, we can now turn to obstetrics, where we find the same ideas about clinical science. We have already encountered these ideas in the lectures of Leopold Lehmann, the Amsterdam obstetrician: for example, in his inaugural lecture of 1865 , in which he mentioned the status of obstetrics as a separate scientific discipline within the unity of medicine, and stated that the distance between the art and the science of obstetrics had been bridged when "better knowledge about the physiology and the mechanism of birth filled the gap and gave the discipline a truly scientific character". He traced the origin of this idea

\footnotetext{
${ }^{37}$ Van Lieburg, op. cit., note 11 above, indicates this point, referring to H. A. Schreuder, 'Ein Blik op Oude en Jonge Geneeskundigen', Wenken en Meeningen omtrent de Geneeskundige Staatsregeling, 1839, 2: 11-33, in which the discussion about how medicine should be conceived and practised is put in terms of arguments between young doctors against old.

${ }^{38} \mathrm{Cf}$. Mendelsohn, op. cit., note 3 above, p. 9.

39 J. Huizinga, Verzamelde Werken, Haarlem, Tjeenk Willink, 1951.

${ }^{40}$ Mendelsohn, op. cit., note 3 above; and Weindling, op. cit., note 5 above, particularly stress this "double" engagement of the German progressive doctors.

${ }^{41}$ Opening lecture of Professor C. A. Pekelharing of the 39th General Meeting of the NMG, 2 July 1888, published in NTG 1888.
} 


\section{Obstetrical research in The Netherlands}

to Germany, "from whence the clear light that now continues to elucidate obstetrics as an exact science par excellence has spread over all the countries of Europe". ${ }^{42}$

Similar statements were made by the other professors of obstetrics in their inaugural lectures. ${ }^{43}$ They all stressed the unity of medicine, but at the same time sought to legitimate its independent status as a scientific discipline by recalling its longstanding tradition and its famous representatives in science, with special reference to Germany. The names of Schroeder, Ruge, Michaelis, Naegele, and Boer were often mentioned. Indeed, obstetrics was a speciality with a history, and not only an art or skill. It was a subject taught in the universities as early as the eighteenth century, but the teaching had been purely theoretical and not given special attention. Surgery, in combination with which it was taught, was thought to have higher status. ${ }^{44}$

In practice, normal deliveries had been almost exclusively the concern of midwives, who were obliged to summon the help of a male midwife or a surgeon in complicated cases, since midwives were not allowed to use instruments or perform operations. The graduate doctores artis obstetricae were called in for help only in exceptional cases. As the practice of midwifery came to be more and more strictly regulated by law and the doctores had to take care of the education and supervision of midwives, the need for more practical training soon became apparent. As a result, in 1848, Abraham Simon Thomas was appointed in Leiden to the first chair of obstetrics and gynaecology separate from surgery. Elsewhere, the chair remained a combination of surgery and obstetrics. The clinical schools taught surgery and obstetrics at a practical level, but here also the two fields were combined. Amsterdam was an exception, with Lehmann appointed in 1848 as reader in obstetrics.

With the introduction of the 1865 law, clinical professors of the clinical subjects were appointed at all the universities. The clinical schools, as we have seen, did not meet the new criteria for medical education, and were closed, except for the Amsterdam school, which maintained a high standard and a good reputation and eventually merged with the Atheneum Illustre, with which it already had strong links because of double appointments of the professors. ${ }^{45}$ As a result of this merger, the Atheneum was in an extraordinarily advantageous position in comparison with the rest of the country. The university professors of Leiden, Utrecht, and Groningen had to make special arrangements with the midwives in order to enlarge the practical training of their students by having them assist in home births, under the supervision of midwives (the so-called secours à domicile). ${ }^{46}$ The university clinics were too small. In their inaugural

\footnotetext{
${ }^{42}$ L. Lehmann, Trapsgewijze Ontwikkeling der Verloskunde als Zelfstandige Wetenschap, voornamelijk in Nederland, Amsterdam, 1864, p. 42.

${ }^{43}$ A. E. Simon Thomas, De Experientia Medico Perquam Necessaria, Annales Academia, Leiden, 8 February 1860; T. Halbertsma, De Voortreffelijkheid der Hedendaagse Verloskunde, Groningen, 1866; W. M. H. Sänger, De Onvolkomenheid der Verloskundige Wetenschap, The Hague 1867; H. Treub, De Verdiensten der Nederlanders op het Gebied der Bekkenleer, Leiden 26 January 1887; G. H. van der Mey, Het Bestaan eener Kraaminrichting "Eene Levensvoorwaarde voor Verloskundig Onderwijs", inaugural lecture published in NTG, 1898, pp. 11-24.

44 This was generally true in Europe, see H. Fassbender, Geschichte der Geburtshülfe, Jena, Fischer, 1906.

${ }^{45}$ Minutes of the meetings of the clinical school professors, Amsterdam Municipal Archive, File $30 \mathrm{nr}$. 24-26; Gedenkboek van Het Atheneum en de Universiteit van Amsterdam 1632-1932, Amsterdam, Stadsdrukkerij Amsterdam, 1932, ch. 'De Geneeskunde'.

${ }^{46} \mathrm{Cf}$. Thomas, op. cit., note 32 above; G. C. Nijhoff, 'Het Onderwijs in de Verloskunde en de Uitoefening der Verloskunst in Nederland Gedurende de Laatste 75 jaren', NTG, 1924, 1: 25-32.
} 
lectures, professors of obstetrics from 1865 onwards pleaded for extension of the obstetrical clinics. ${ }^{47}$ When in 1895, Treub, the successor of Simon Thomas in Leiden, was offered the chair in Amsterdam, he accepted immediately because Amsterdam provided him with a bigger obstetrical clinic and a bigger gynaecological clinic and polyclinic. $^{48}$

The new professors of obstetrics appointed in 1865, all representatives of "modern" medicine, took their educational tasks very seriously, convinced as they were that only this new approach to medicine could provide the rational knowledge necessary for a doctor to treat his patients adequately ${ }^{49}$ The emphasis on teaching is also apparent in the effort the new professors put into the writing of textbooks. Simon Thomas wrote a little textbook ${ }^{50}$ his successor, Treub, published a two-volume textbook on gynaecology; ${ }^{51}$ Van der Mey, the successor of Lehmann in Amsterdam, began a major textbook on obstetrics that was completed by Treub, ${ }^{52}$ who completely reworked the third edition into a new textbook. ${ }^{53}$ Sänger in Groningen also published a handbook on obstetrics. ${ }^{54}$

This emphasis on education raises the questions of how these propagators of modern medicine approached their newly established positions in the university, how they perceived their roles as clinical scientists, and what this meant in terms of the relative emphasis on teaching and research. The Dutch obstetricians did produce certain clinical research results that were known also outside of Holland. Simon Thomas, professor in Leiden from 1848 to 1886 , gained recognition for his study of the unevenly narrowed pelvis, inspired by the great work of Michaelis on the mensuration of the pelvis. ${ }^{55}$ Simon Thomas introduced this work in Holland, ${ }^{56}$ but could not approach the enormous number of measurements that Michaelis had made in order to make his classifications and establish his concept of the normal pelvis. ${ }^{57}$ Another contribution of Simon Thomas was in the field of gynaecology, in which he published an account of twelve cases of ovariotomy, then a rather novel operation, ${ }^{58}$ and a new technique for the closing of the uterus after caesarian section. ${ }^{59}$ Halbertsma, professor

${ }^{47}$ See note 43 above, and H. Treub, De Gevaren der Hedendaagse Gynecologie, Leiden, 1896; J. Veit, Die Ziele des geburtshülflich-gynecologischen Unterrichts, Leiden, 1896. The following quotation from Goudsmit, op. cit., note 8 above, p. 31, is also relevant: "In the years 1851-65 the investments in the universities only increased from $10 / 00$ to $20 / 00$ of the state expenditures. The expenditures for provisions of the whole of higher education amounted in 1851 only up to one third of the expenditures for the stimulation of fishery."

48 Treub, op. cit., note 47 above.

49 See inaugural lectures cited in note 43 above.

50 A. E. Simon Thomas, De Leer van het Onderzoek voor Verloskundigen en vrouwenartsen, Leiden, 1867.

${ }^{51}$ H. Treub, Leerboek der Gynecologie, 2 vols., Leiden, 1892; 2nd rev. ed. (1895); 3rd rev. ed. (1898); 1 -volume 4th revised edition (1903); 5 th revised edition (1910).

52 G. H. van der Mey, Leerboek der Verloskunde, vol. 1, Haarlem, 1898; vol. 2, Haarlem, 1900.

${ }^{53}$ H. Treub, Leerboek der Verloskunde, 3rd rev. ed., Haarlem, 1905; 4th rev. ed. (1909); 5th rev. ed. (1913); 6th rev. ed. (1919).

54 W. H. M. Sänger, Handboek der Verloskunde, Groningen, 1837; 2nd rev. ed. (1881); 3rd rev. ed. (1888); 4th rev. ed. (1896).

${ }_{55}$ A. E. Simon Thomas, Das schrägverengte Becken von Seite der Theorie und Praxis nach dem gegenwärtigen Stand der Wissenschaft, Leiden, 1861.

56 A. E. Simon Thomas, 'De Leer der Bekkenvernauwing nader Toegelicht', NTG, 1857, p. 675.

${ }^{57}$ G. A. Michaelis, Das enge Becken nach eigenen Betrachtungen und Untersuchungen, Leipzig, 1851.

58 A. E. Simon Thomas, 'Twaalf Ovariotomieën', NTG, 1876, 2: 179.

59 A. E. Simon Thomas, 'Sectio Caesarea. Sluiting der Baarmoedermond door Zilverdraad-hechtigen en Volkomen Sluiting der Buikwond. Ongestoord Verloop van het Kraambed', NTG, 1896, 1: 493. 


\section{Obstetrical research in The Netherlands}

in Groningen in 1866/67 and from 1867 onwards in Utrecht, became known outside the country for his work on eclampsia. ${ }^{60}$ Sänger, professor in Groningen from 1867 to 1898 , acquired a reputation for his work on vaginal uterus extirpation. ${ }^{61}$

All this work, however, mostly dealt with special cases, so that only a few case descriptions were required before a scientific report could be published. The Dutch could not keep pace with the experimental research that became so predominant from about 1850, especially in Germany. In the 1860s, German research dealt chiefly with physiological measurements; in the '70s with the role of the kidneys in pregnancy and with the innervation of the uterus; in the ' 80 s on pelvic measurements with instruments, ectopic pregnancies, the physiology of the placenta and the foetus. ${ }^{62}$ Only Halbertsma in Utrecht made contributions in this area, no doubt profiting from the "experimental" climate there and from Donders' well-equipped physiological laboratory. Yet it remained virtually impossible to match the major clinical studies from abroad, in which new theories and experimentally established hypotheses could be put to the test. This lack of research activity is also reflected in the articles that appeared in the Dutch Journal for Obstetrics and Gynaecology (NTvVG). This journal, established in 1889 by the Dutch Association for Gynaecology, long suffered a precarious existence. Its first two volumes mainly contained articles from the Leiden and Amsterdam clinics; but the number of such articles gradually declined from twenty-four in its first two years, to nine in the last two years of the century. From the third year onward, it was filled primarily with the contributions of doctors with private practices. A strong orientation towards German research is also visible in the content of the articles before 1900 . Of all the references, 55-80 per cent were to German sources; 5-35 per cent to French sources; and 4-20 per cent to Dutch sources. Gynaecological articles, and especially those on operations, formed the main part of the journal in the first years, but from 1893, they gradually gave way to articles on the physiology of pregnancy or the female organs, or on complicated deliveries and pelvimetry. The enthusiasm for gynaecological operations was so great that some doctors spoke of the "operating fury" that had taken over. By the end of the century, the growing concern about this development was reflected in the inaugural lectures of professors. Treub, for example, in a lecture on 'The danger of contemporary gynaecology', warned against careless diagnosis and casual decisions to operate. The connexion between gynaecology and obstetrics was emphasized, as was the relevance of the non-operative gynaecology.

Another available source which allows us to reconstruct the nature and amount of scientific work produced in Holland consists of dissertations. The publication of regular discussion in the $N T v V G$ of all dissertations published from 1889-95 is of help here. With an average of some five dissertations per year, there were not many to review. During this six-year period, there were no dissertations from Groningen, only one from Utrecht, seven from Amsterdam, and twenty-six from Leiden written under the supervision of Treub. Almost all dealt with theoretical considerations based on literature, with descriptions of a very limited number of cases, or with a report of the

${ }^{60} \mathrm{~J}$. Halbertsma, 'Die Aetiologie der Ecclampsia Puerperalis', Vollkmanns klinische Vorträge, no. 212.

${ }^{61}$ W. H. M. Sänger, 'Extirpatie der Baarmoeder vanuit de Schede', NTG, 18: 261-236.

62 Fassbender, op. cit., note 44 above, pp. 378-798. 


\section{Anja Hiddinga}

clinic over a certain period. The case descriptions often of one or two observations made while working as an assistant in the university clinic, augmented with some observations from private practice, which was usually established after the assistantship, or with some reports of cases treated by the professor or other doctors.

Thus we have to conclude that during the nineteenth century, no research tradition in obstetrics was established in Holland as had been the case in Germany, where the prevailing ideas seem to have been similar. This was so, despite the facts that Dutch doctors were convinced by the idea of clinical science, and had promoted this idea against more conservative currents by emphasizing scientific knowledge as the basis for the furtherance of medicine; that they had won their fight for a medical education completely located in the university and intrinsically connected with scientific research; and that many prominent natural scientists were working in the Dutch universities and favoured a climate conducive to scientific research. Why was this so? To answer it we must examine clinical practice, which is of such vital importance for clinical research. Since Germany served as a model for Holland, a comparison of the conditions of clinical practice in the two countries should be helpful in elucidating those factors in clinical practice that are important in explaining the differences.

\section{The Conditions of Clinical Practice in Holland and Germany Compared}

In Germany there were more, larger, and better-equipped clinics than in Holland. ${ }^{63}$ These provided more opportunities for research and education. In Holland, there were no trained nurses: nursing personnel were recruited from penal institutions, and the descriptions of the deplorable and unhygienic circumstances of patients lying in dark, unventilated rooms, and having to bribe nurses to obtain the food and wine to which they were entitled, speak for themselves. ${ }^{64}$ These circumstances were not very favourable to clinical investigations. It was not until 1883 that training for nurses was introduced in the Amsterdam clinic, the biggest in the country, not surprisingly by German "sisters". No qualified people could be found in Holland to set up nursing care in the hospital. Since the 1870s, when private hospitals with proper furnishings and nursing had been established, the deplorable Amsterdam university clinic had found itself competing with these for patients. ${ }^{65}$ Moreover, in 1871, everyone entering the hospital, patients and visitors alike, had to pay for admission, and when a patient died, his relatives had to pay for the removal of the corpse. The medical professors tried to overcome this rule by distributing their visiting-cards for free admittance. ${ }^{66}$ Although this situation improved during the last quarter of the century, an 1882 hospital board report about the state of the hospitals described the situation as completely intolerable. ${ }^{67}$

\footnotetext{
${ }^{63}$ See notes 89 and 93 below, and also the statements cited by C. van Tussenbroek, De Ontwikkeling der Aseptische Verloskunde in Nederland, Haarlem, De Erven F. Bohn, 1911, p. 52, 53, from J. Dietl's report from 1852 about the Amsterdam hospitals.

64 Ibid., pp. 52, 53; also J. W. R. Tilanus and C. H. Kuhn, Rapport van de Faculteit der Geneeskunde inzake de Amsterdamse Kraaminrichting, Amsterdam, 1879; Verdoorn, op. cit. note 8 above, pp. 131-150.

${ }^{65} \mathrm{G}$. Hellinga, 'De Gasthuisquestie', in Gedenkboek, op. cit., note 45 above, Ch. IVb, pp. 417-430; Verdoorn, op. cit., note 8 above, pp. 131-141.

${ }^{66}$ De Moulin, op. cit., note 21 above.

${ }^{67}$ P. A. Brugmans et al., Rapport inzake de Klachten over de Verpleging in het Binnengasthuis, Amsterdam, 1882; also, C. C. Delprat, 'De Reorganisatie van de Verpleging in de Gasthuizen en de Bouw van het Academisch Ziekenhuis, 1883-1932', in Gedenkboek, op. cit., note 45 above, ch. IVc, pp. $430-474$.
} 


\section{Obstetrical research in The Netherlands}

Another difference between the two countries was their clinical laboratories. Führbringer, a professor of anatomy in Amsterdam of German origin, complained about the state of the laboratories, as did his successor and fellow-countryman, Ruge. ${ }^{68}$ Sometimes, professors threatened to accept jobs elsewhere, or raised private funds to set up special clinics. A colleague of Donders in Amsterdam refused to accept a professorship in ophthalmology in 1894 without a better-equipped clinic, something accomplished by a huge legacy. ${ }^{69}$

As the examples of Führbringer and Ruge make clear, the orientation of Dutch medicine towards Germany was at that time apparent not only in references to German literature and to German medical scientists, but also in the fact that a number of doctors went to Germany to study and work in the universities there, and that Germans were appointed as professors in Holland. ${ }^{70}$ Despite legislation to the effect that no foreigners should be appointed as professors, several, in fact, were. ${ }^{71}$ For example, Hertz became professor of special pathological anatomy in 1867-he was not only German, but had been proposed for the professorship by Virchow himself. Hertz actively promoted clinical education in Amsterdam. Kuhn, Van Geuns' successor appointed in 1877, was a Dutchman, but he had worked in Germany with Virchow and Von Recklinghausen. None of the Germans stayed very long, however, and most of them eventually returned to their own country. It is likely that the situation of the clinics played a role here. This can be illustrated in the case of obstetrics. As J. Veit, a German professor in Leiden from 1896 to 1903, described the situation there: "the clinical material was small, even smaller than in my private practice in Berlin". Veit started his own research, "making use of the only material that was available to me in sufficient quantities, i.e. placentae". During his time in Leiden, he saw the number of deliveries rise from 128 to 165 per year, while cases in the gynaecological clinic rose from 189 to 300 , and in the gynaecological polyclinic from 248 to $590 .^{72}$ After his professorship in Leiden, he accepted a chair in Erlangen, and, a year later, one in Halle, "where I can make use of ample material, i.e., in the obstetrical clinic approximately 700 cases, the gynaecological clinic more than 1000 cases, and in the gynaecological polyclinic 3500 cases."73 Veit was not the only one who left. Döderlein, appointed in Groningen in 1897, left for Germany again after only three months; Güsserow in

68 W. P. C. Zeeman, 'De Geneeskunde', in ibid., ch. 3, 2nd section, p. 163.

${ }^{69}$ Prof. M. Straub made the following statement in his inaugural lecture (M. Straub, De Vorming der Geneeskundigen, Amsterdam, 1895): "I would not have accepted the resources given to me now, if I had not known that this institute will only have to serve temporarily and that an installation will be created by the princely Borski legacy that will amply serve the treatment of eye sufferers and the education of students." This statement was quoted with approval by the rector of the university, J. C. Matthes, in his annual speech to the university population, Jaarboek der Universiteit van Amsterdam 1894-1895.

70 This seems to have been the case much longer. D. de Moulin ('Die Medizin zur Zeit der Regierung des Königs Wilhelm I in den Niederlanden (1813-1840)'. Janus, 1978, 45: 21-44) describes this orientation and the importation of German doctors as something already apparent in the seventeenth century. The Germans were present not only as practising doctors and university teachers, they also sat on editorial boards of medical journals and practised as military doctors.

71 This legislation dates from 8 August 1822 . No foreigners were allowed to be appointed as a professor, without naturalization. Cf. J. P. Fockema Andrea, 'Het Academisch Bestuur (1815-1877)', ch. 1. in Fockema Andrea et al. op. cit., note 30 above, vol. 2, p. 11-26.

$72 \mathrm{~J}$. Veit in an autobiographical description of his activities in Leiden to Thomas, op. cit., note 32 above, p. 91.

${ }^{73}$ Ibid., p. 91. 


\section{Anja Hiddinga}

Utrecht stayed only a year (1867-8); and the proposed German successor of Lehmann in Amsterdam, Zweifel, did not even accept the chair. ${ }^{74}$ That all these were Germans is a remarkable fact. In the previous section we saw the extent to which the Dutch modern medical scientists were oriented towards Germany. This orientation is so overwhelming that complaints about the Germanization of the language and of Dutch medicine began to be voiced in the NTG. ${ }^{75}$ This last point was raised by Treub in his protest against Döderlein's appointment, which caused a break in contact with Veit and accounts for the fact that the Germans stayed away from the third international congress of gynaecology and obstetrics, held in Amsterdam in $1899 .{ }^{76}$

Veit's report of his professorship in Leiden contains also a striking complaint about the closing of the clinic during student vacations. Veit initiated a discussion in the NTG to have his state of affairs changed. ${ }^{77} \mathrm{He}$ was struck by the extent to which his Dutch colleagues viewed the clinics more as training grounds for students than as places in which to do research. And, of course, education was the major concern of the clinical disciplines. After 1865 , they were suddenly confronted with a large number of students who had to receive practical training.

As we have seen, one of the major difficulties of the obstetricians was their lack of clinical material. Amsterdam was an exception to this, and therefore we could expect more research to be done there, where Lehmann, the promoter of scientific obstetrics, was a professor. As we have already seen, however, the Amsterdam clinic was in a deplorable state with respect to hygiene and nursing. That it also extended to the Amsterdam maternity clinic, which after 1867 was housed in a new larger building with 106 beds, can be seen from discussions between the faculty and the city authorities about its closure, as well as contemporary brochures. It appears that of the 106 beds, an average of 20-24 were occupied by pregnant women, while the rest were filled with sick children, sufferers from eye diseases, and patients recovering from surgery. ${ }^{78}$ According to another report, 615 fewer women came to the new clinic during the first six years of its existence than had come to the old clinic in the course of the previous six years. Moreover, Lehmann was strongly opposed to the idea of puerperal fever as a contagious disease: in fact, he followed Virchow, for whom contagion resembled too much the ontological conception of disease. ${ }^{79}$ This meant that the university clinic was frequently ravaged by the disease. The mortality among women in the clinic increased from four per cent in the years $1865-76$, to eight per cent in 1877 , to fourteen per cent in

\footnotetext{
${ }^{74}$ Van Tussenbroek, op. cit., note 63 above, p. 88; C. N. van der Poll, 'Professor G. H. van der Mey Jr.', $N T v V G, 1895,7: 4$.

${ }^{75}$ Regular complaints were made in $N T G$, mostly in concluding remarks in book reviews or in letters to the editor. This point is made explicitly in an open letter in $N T G, 1882,2: 192$, and especially in the writings of H. Treub, 'Over medische Studenten, medisch Onderwijs en medische Professoren in Nederland', NTG, 1891, 2: 65, and in his later brochure Universität und Vaterland, Amsterdam, 1888-1889.

${ }^{76}$ Treub, op. cit., note 43 above; B. J. Kouwer, 'De Nederlandse Gynecologische Veregiging en Het Nederlands Tijdschrift voor Verloskunde en Gynecologie 1887-1931', introduction to the register of the index of $N T v V G, 1931$, p. $21,22$.

77 J. Veit, 'Vacantie-cursussen', NTG, 1897, 2: 862.

78 A. W. C. Berns, De Opheffing van de Amsterdamse Kraaminrichting nader Besproken, Amsterdam, 1881.

${ }^{79}$ See ibid., pp. $260-275$, for an extensive treatment of Virchow's position in the discussion about puerperal fever.
} 


\section{Obstetrical research in The Netherlands}

the first few months of 1878 . This was one reason why the city authorities closed the clinic in May of that year ${ }^{80}$ Women feared to go there to deliver their babies, and only the extremely poor, who could not even afford to pay a midwife, would go. Although, in 1846, Semmelweis had convincingly demonstrated the effect of antiseptic measures on the death rate in maternity clinics, many "modern" doctors refused to believe in the contagious origins of illness. ${ }^{81}$ As Catharina van Tussenbroek remarked in her study on aseptic obstetrics in The Netherlands, "It was Virchow's authority in Holland that stood in the way of Semmelweis's acknowledgement". ${ }^{82}$ Until his death, Lehmann remained a convinced disbeliever. His physiological studies may indeed have been a major factor contributing to the propagation of this deadly disease, since, for example, he apparently used the same thermometer for healthy and sick women, to measure the temperature in the uterus before, during, and after delivery. ${ }^{83}$

After Lehmann's death in 1880, his successor, Van der Mey, in a few years brought down the death rate in the clinic through the introduction of anti- and a-septic measures. And, although he contributed some articles to the first issues of $N T v V G$, his energy seems to have been directed more to the improvement of the conditions for the development of gynaecology in Amsterdam, a subject that had been somewhat neglected by Lehmann. Moreover, moving the university clinics to another hospital meant that for a while part of the department was housed in an old canal house: a situation far from favourable to clinical research.

In conclusion, we can say that in comparison with Germany, clinical practice in obstetrics in Holland was characterized by small hospitals, bad nursing conditions, little clinical material, and badly-equipped clinical laboratories. Even in the relatively favourable situation of Amsterdam, the conditions were such that clinical research could not begin to develop. More importantly, the Dutch clinics remained primarily oriented to the education of students, a situation brought about by a conception of scientific medicine that was shaped by the professionalization process.

\section{The INSTITUTIONAL SetTing OF OBStetrics}

The availability of clinical material was a significant respect in which Dutch obstetrical practice differed from that in Germany. But it can only be one element in an explanation of the failure to develop a Dutch obstetrical research tradition comparable with that in Germany. The discussion of the process of professionalization among the Dutch doctors showed that a strong emphasis was put on medical education. Demands for university training were not only to raise the level of the knowledge of doctors, but also to assert the special status of medical knowledge. Before 1876, this argument played an important role in the professionalization strategy of the graduate doctors in

\footnotetext{
${ }^{80}$ For an account of the conflict between Lehmann and the City authorities, see van Tussenbroek, op. cit., note 63 above, p. $80 \mathrm{ff}$. The clinic was closed down from May to September 1878, November to January $1880-81$.

${ }^{81}$ Cf. R. Cooter, 'Anticontagionism and history's medical record', in P. Wright and A. Treacher (editors), The problem of medical knowledge, Edinburgh University Press, 1982, about the relationship between medicine and ideology in the case of anticontagionism. For a more thorough and interesting account, though, one should read the study (criticized by Cooter) by E. H. Ackerknecht, 'Anticontagionism between 1821 and 1867', Bull. Hist. Med., 1948, 22: 562-593.

82 Van Tussenbroek, op. cit., note 63 above, p. 31.

${ }^{83}$ L. Lehmann, 'Over de Bepaling der Dierlijke Warmte bij Puerperaal Processen', NTG, 1865, 2:391.
} 


\section{Anja Hiddinga}

their competition against the non-graduates. As a result, education was strongly emphasized within the university setting of clinical medicine. Clinical science thus came to be equated more with scientific education in the clinic than with research. Apparently, the idea of a clinical science as a "real" science was still such a charged issue that Treub, talking in 1899 about clinical obstetrical science in a lecture to the NMG, remarked: "I don't have to excuse myself for talking of clinical science, do I?"84

As already noted, this preoccupation with education is not only present in almost every inaugural lecture and voiced repeatedly in public speeches and reports, but also apparent in the fact that so many obstetricians put their efforts into the writing of textbooks. Still, the doctors were not totally unaware of the problems of combining research with education, as is apparent from a statement made at the yearly lecture to the assembly of the NMG in 1888 :

In the question of the education of doctors the great difficulty is that we are all convinced that science, above all, should provide a basis for education, but that we do not know exactly how to make room for pure science in education without failing to meet the demands of practice. This difficulty has been present in our Association for years. Here also the question has been: what place should we give to science, the pursuit of which has been the explicit objective of the Association? ${ }^{85}$

The doctors were not alone in looking upon the university in this manner, and we need to consider the broader set of expectations addressed to the Dutch universities in the latter part of the nineteenth century.

At least so far as medicine was concerned, the universities were seen primarily as training grounds for students and not as places in which to do research. The loss of students, for example, meant that the very existence of the university was endangered, as in the case of Groningen. In Amsterdam as late as the 1890s, the city council proposed to close down the university because it cost too much money for too few students, and only served as "an institute for hobbyists", or as "an unnecessary, reckless, irresponsible luxury". 86 This was said at a time when Van 't Hoff and Van der Waals in the same university had established international scientific reputations as researchers. The extent to which similar problems were faced in other sciences is not clear. This question remains to be answered by studies of the history of the development of Dutch universities. ${ }^{87}$ That the state was reluctant to provide the necessary money to extend and improve laboratories is apparent from the many pleas 128.

${ }^{84} \mathrm{H}$. Treub in a lecture held at the general meeting of the NMG, 3 July 1899, published in NTG, 1899, 2:

${ }^{85} \mathrm{C}$. A. Pekelharing in his opening lecture to the 39th general meeting of the NMG, published in NTG, 1888, 2: 7. In 1891, Treub proposed to separate the education again in a practically- and a scientificallyoriented direction, although not with the same differences in licensing as before the 1865 law. He thinks to realize this by reducing the number of universities from 4 to 2 and by turning the disappearing two into medical schools!

${ }^{86}$ Prof. C. M. Kan cited these statements from the Municipal Journal, in his speech to the University of Amsterdam staff and students on the occasion of handing over the rectorship: 'Verslag van de Lotgevallen van de Universiteit van Amsterdam', Jaarboek der Universiteit van Amsterdam 1892-1893, Amsterdam, 1894, p. 6.

${ }^{87}$ An example from the natural sciences is that of Van 't Hoff, very well-known internationally, who "considered" taking up a professorship offered to him in Leipzig in 1891. The rector stated that year in his annual speech to the university population: "The new and outstanding [chemical] laboratory ... is a lasting 


\section{Obstetrical research in The Netherlands}

for funds for this purpose, which were rejected by the authorities with sceptical remarks about pure science. ${ }^{88}$

In his report to the NMG on the comparison between higher medical education in Germany and Holland, Treub stated that "the clinical laboratories are generally much better in Germany than in Holland", 89 and he also called attention to another important difference, in the number of assistants. Not only was the scientific medical staff much larger in Germany, but they also held better positions and were better paid. In Holland before 1879, the assistants to the professors were students of medicine, and although from that year they were required to be doctors who had completed their studies, salaries were so low that it was hard to keep anybody for more than one or two years. ${ }^{90}$ In fact, even the professors were poorly paid. When Donders, for example, left his teaching job in a school in The Hague for a university chair in Utrecht, his salary was cut by more than half, so that he had to do translations in the evenings to support his family. ${ }^{91}$

Another factor was the disincentive to produce dissertations. With the introduction of the title of Arts (doctor), the need to write a dissertation in order to graduate and acquire a licence to practise had disappeared. And since there was little incentive after 1865 in the form of senior posts, extra pay, or professional status, the number of dissertations remained small. The fact that it was relatively easy to acquire the title of "doctor" in some German states or Belgium (where the writing of a dissertation was not required) also dampened enthusiasm for graduating with a dissertation in Holland.

The fact that the public makes no distinction between those who have and those who have not written a doctoral dissertation and, moreover, that all who return after a short trip abroad with a German "Doctor's diploma" can carry this title with impunity, may serve as an excuse. But we

result of Van 't Hoff's call to Leipzig and of his decision, so gratefully received by everyone who loves Dutch Science, to remain loyal to Amsterdam despite the attractiveness and honour of the call." (Quoted in the yearly lecture of the rector to the University of Amsterdam in Jaarboek der Universiteit van Amsterdam 1891-1892, Amsterdam, 1894, p. 12.) When he later did accept a chair in Berlin, it was not only the better-equipped laboratories that persuaded him to go, but also the fact that he hardly had to do any teaching and could devote himself almost exclusively to research. (cf. Levensberichten van Professoren en Lectoren, Aanhangsel behoorende tot het Gedenkboek van de Universiteit van Amsterdam, Amsterdam, Stadsdrukkerij Amsterdam, 1932, p. 602) Studies on the development of Dutch universities are unfortunately lacking at the moment, as are so many other parts of Dutch historiography. The only available relevant study deals with the early development of the group of Dutch graduates: W.TH.M. Frijhoff, La Société Néerlandaise et ses gradués, 1575-1814, Amsterdam, APA/Holland and University Press, 1981.

${ }^{88}$ This attitude was apparent, e.g., in the reaction to the City Council to Van Geuns' request for money to extend the pathological-clinical laboratory, in which the authorities stated that "the institute [the laboratory] only has to meet the needs of education and not those of science as well", and they declined his request for this reason. (J. van Geuns) Adres aan de Amsterdamsch Germeenteraad. Het Pathologisch-Klinisch Laboratorium te Amsterdam. Amsterdam, c. 1870, p. 11. See also the account of the discussion with the Leiden City Council about the rebuilding of the Leiden clinic in Thomas, op. cit., note 32 above; W. Koster, De Opleiding der Artsen en de Vermindering der Staatsuitgaven voor het Hooger Onderwijs, Utrecht, 1882; Characteristic are also the pleas made in the inaugural lectures (notes 43 and 47 above) and notes 67 and 84 .

${ }_{89}$ H. Treub, "Een en Ander ter Vergelijking van het Medisch Hooger Onderwijs in Nederland en Duitsland', $N T G, 1896,1: 379$. Report in request of the Minister of Internal Affairs.

${ }_{90}$ Fockema-Andrea $e t$ al., op. cit., note 30 above, pp. 215-281.

${ }^{91}$ Cf. J. and A. Romein, Erflaters van Onze Beschaving, Amsterdam, Querido, 1976, p. 675-699; P. H. Kylstra, 'Franciscus C. Donders (1818-1889)', in A. J. Kox and M. Chamalaun (editors), Van Stevin tot Lorentz, Amsterdam, Intermediair, 1980, pp. 135-149. 


\section{Anja Hiddinga}

have to fear that in this way a title which for centuries conveyed a high status in social life will become stigmatized as a foolish eccentricity, probably even a ridiculous arrogance to make colleagues envious. Caveant consules. ${ }^{92}$

Looking somewhat closer at the dissertations that were written in obstetrics, we see that these still had the traditional character of a theoretical piece of work, mostly based on a study of the literature without clinical research. It is characteristic that most of them were written in Leiden, and almost none in Amsterdam, which should have been the most favourable place for clinical research. The medical dissertation in Holland was still located in the historical context of these two universities: conservative Leiden, where a graduation in medicine was traditionally a theoretical piece of work, and modern Amsterdam, where there was no tradition of writing a dissertation at all, since the university-to-be lacked the ius examinandi until 1877 . So here, too, we have to conclude that one of the obvious ways in which to do research, namely in the framework of a graduate study, was inhibited by the fact that no new institutional incentives to write dissertations were created. The thesis preserved its historical form even though its function had lost its traditional meaning under the new legislation, and was accorded no new significance by the creation of careers in science. In fact, there existed hardly any opportunities for a scientific career: "one cannot blame ... the young doctor if his eagerness to do scientific work is not very great, when there is no future, in whatever form, connected with it." 93

The lack of opportunity to do scientific work was also given as a reason why foreigners often occupied chairs in the universities. It seemed that no sufficiently qualified Dutch candidates were available: "Our medical faculties do produce many skilful people ... but they offer the students little or no opportunity to engage in long, continuing scientific research, and this is one of the reasons why almost every time a chair has to be filled anew, the choice among our young doctors ... is only a very limited one." $" 94$

Both the loss of the social function of the dissertation and the fact that no new careers in science emerged in the Dutch universities contributed to the low number of dissertations produced. This, together with the difference in this respect between Leiden and Amsterdam, indicates that the university maintained its traditional position with respect to medicine; although the idea of clinical research was introduced, the university did not function as a research institute.

One last issue to be considered in the discussion of institutional arrangements is the size of the country. In the first place, this factor is, of course, responsible up to a point for the size of hospitals and the number of patients. If we again make the comparison with Germany, we see that in the last quarter of the nineteenth century, there were twenty universities in Germany with twenty-one women's clinics (Berlin had two clinics) all built after 1860, providing the doctors there with 10,000 deliveries and an equal number of gynaecological cases every year. In addition to professors and

${ }^{92} \mathrm{G}$. C. Nijhoff wrote this in one of his regular reviews of dissertations in obstetrics in $N T v V G, 1889$, p. 248.

${ }_{93}$ Treub, op. cit., note 47 above, p. 385.

${ }^{94}$ In an editorial annoucement in Weekblad van het Nederlandsch Tijdschrift voor Geneeskunde, no. 18, 1897, 1: 701 . 
assistants, there were doctors working voluntarily in fourteen of the clinics in 1893. Moreover, every university also had obstetrical and gynaecological polyclinics. ${ }^{95}$ By comparison, Holland had four university women's clinics, three of them with polyclinics, with a total of some 600 deliveries a year until the beginning of the 1880 s. From 1880 until the end of the century, the number rose to approximately 850 a year. Amsterdam represented by far the highest number of deliveries, from 350 to some $500 \mathrm{a}$ year by the end of the century. ${ }^{96}$ What is to be noted here is not so much the size of each clinic: rather the point is that the overall clinical activity, the number of professorships, and the number of doctors involved in university clinics, all created in Germany an atmosphere that must have been quite different from the homely, friendly atmosphere in The Netherlands. Again, we can find indications in support of this hypothesis in institutional arrangements. The Amsterdam Gynaecological Association was established in 1887 by the Amsterdam professor of obstetrics and gynaecology, van der Mey, and some doctors with private practices, all graduates in obstetrics and gynaecology. Their objective was to talk about "special issues in their field of science", and the association was rebaptized the Dutch Association of Gynaecology (Neederlandse Gynecologische Vereniging, NGV). Treub in Leiden and van der Mey in Amsterdam were especially active in the association. At meetings, usually with no more than seven or eight members present, they would examine patients under narcosis, show preparations, or lecture about difficult deliveries and operations. Foreign articles and books were also discussed. "In accordance with the jovial character that typified our meetings, we often examined patients difficult to diagnose, and all who were present took part in the discussion." Furthermore: "Eating together, a thing that sociable doctors fortunately have always appreciated, seduced us in 1901 not to meet at all in July, but instead to have a feast for no other reason, as is mentioned in the minutes, than 'that summer is here'."97 Apparently, the attempts that were made towards the end of the century to change the character of the association were not really succesful even in 1901. But we do gradually see an awareness of its "kind-hearted cosiness", 98 and a desire to change it. The organization of the third international congress of gynaecology and obstetrics in Amsterdam by the NGV contributed to this, as did the decision to publish the reports of the meetings of the association in the Zentralblatt für Gynecologie.99 "All this indicates that our Association is going through a metamorphosis; the small, cosy Amsterdam circle of years gone by will develop into a real, official Association .... We should not want to go back to those bygone days .... It [the Association] can become a scientific and ethical force to the benefit of the whole country...."100

The journal of the Association also suffered from the fact that so few people were involved: "Once again it has to be stated openly here that more than once the editorial

\footnotetext{
${ }^{95}$ Data given by Fassbender, op. cit., note 44 above, p. 279.

96 Data from tables given in van Tussenbroek, op. cit., note 63 above, pp. 136, 86.

${ }^{97}$ Quoted by Kouwer, op. cit., note 76 above, p. 15, from the minutes of the Dutch Gynaecological Association (NGV).

98 Terminology used in the yearly report of the NGV, published in $N T v V G, 1897$, p. 322.

99 Yearly report of the NGV, published in NTvVG, 1897, pp. 321-323.

100 Ibid., p. 323.
} 


\section{Anja Hiddinga}

board had to deal with such a dearth of copy that it was not always possible to publish a volume in time." 101 And indeed, foreign obstetricians wondered about the fact that the Association could keep a specialist journal going in such a small linguistic area. ${ }^{102}$

We have to wonder whether the small, cosy, circle-of-friends atmosphere that typified Dutch obstetrics could have influenced the attitude of the obstetricians towards research. Reading the minutes, the reports, and the retrospects, we get a picture of hard-working, skilful, individually operating doctors who liked to lecture, report, and discuss their practical work in these informal meetings. Daily problems in obstetrical practice took up much of their attention. ${ }^{103}$ Remembering his time in Leiden, Veit said: "I profited especially from encounters with very brilliant physicists in this work [on placentae], by whose information I hoped to find a way to understand foetal metabolism better. In this way I studied the osmotic pressure with Dekhuyzen and the intrusion of flocks in the bloodstream with Hoffman, and so I got into the field in which I still work, and never would I have been able to develop it if my encounters with Kamerling Onnes and others in Leiden had not been so easy." If we consider why Dutch obstetricians did not seek the same co-operation with natural scientists as Veit did, we can only guess that the particular "provincial" setting of Dutch obstetrical science was an important factor. Even as late as 1920, the members of the Association could only sigh over the loss of the regular contributions of a pathological anatomist, who left their circle when he was appointed a professor: "The hope ... that he would return to us, who would have received him in warm friendship, failed to materialize." 104 If we compare this attitude with Veit's active search for co-operation, we can only marvel at such expectant inertia.

To conclude: the institutional setting of Dutch obstetrics in the nineteenth century was unfavourable to the growth of research activities in this field. This situation resulted from the particular circumstances under which the process of professionalization took place, which strongly emphasized the educational side of scientific medicine. But it also resulted from the fact that the traditional climate in the universities remained much the same after the reorganization of medical education in 1865 , which contributed to the "provincial" atmosphere that prevailed in Dutch obstetrics.

\section{Conclusions}

In the first place, I have suggested that the struggle for professionalization within Dutch medicine, and the strategy adopted by the reformers, gave a particular emphasis to the idea of scientific medicine: an emphasis on education, on the provision of knowledge for use in practice. This background of professionalization, which characterized Dutch medicine up to the late 1870s, served to unite the graduate doctors in their competition with other practitioners. This is diametrically opposed to the situation in Germany, where scientific medicine was heavily influenced by the ideas of

${ }^{101}$ Kouwer, op. cit., note 76 above, p. 31.

102 Ibid., p. 30.

${ }^{103}$ Yearly reports in $N T \nu V G 1889$ to 1900 are in this respect indicative as well as the minutes of the meetings of the NGV, also published in NTvVG.

${ }^{104}$ Kouwer, op. cit., note 76 above, p. 21. 


\section{Obstetrical research in The Netherlands}

von Humboldt, who emphasized pure research as the main objective of the scientist and the freedom of teaching and the unity of teaching and research as the leading principles of the universities. ${ }^{105}$ The influence of these ideas created an atmosphere at the German universities that was very much oriented to research, and it became the condition for the establishment of the "research imperative"106 connected with another professionalization process, that of university teachers. There was competition among medical scientists not in terms of acquiring professional independence as a doctor, but in terms of acquiring status as a researcher. ${ }^{107}$ The concept of scientific medicine thus had a double significance for its Dutch promoters, embodying both the ideal of what medicine should be (taken over from Germany) and a sense of the professionalization strategies developed within their own Dutch context.

The outcome of their struggle was the establishment of medical training in the universities, which provided them (bearing in mind their concept of medical science) with conditions that appeared favourable to those who looked to the establishment of a research tradition. So indeed it must have seemed to the German bearers of a comparable tradition who came to the Dutch universities. But achievements in research were limited, and the Germans usually returned home disappointed. A university setting and an unquestioned belief that medicine "ought to be a science", were not sufficient conditions for the establishment of a research tradition. By comparing the situation in Germany with that in Holland I have tried to deal also with the question of why this was so. A partial explanation may be as follows.

First, although the ideal of clinical science in Holland, as in Germany, was promoted by a group of young enthusiastic doctors reacting against a conservative and romantic approach to medicine - in a context of great social instability - the romantic tradition was far less deeply rooted in Holland. A milder reaction thus seems at least plausible. The Dutch doctors, moreover, were not so involved in social and political reform as their German counterparts, and Dutch attempts to change medicine were not part of a broader movement of social reform as was the case in Germany. This broader political involvement seems to have been a source of strength to the German group (as well as an influence on their intellectual development). The Dutch doctors, in contrast, were more closely bound to a narrow conception of professional interests, involving essentially the search for control over education and licensing.

Second, for the German visitors there were, of course, no such ideological constraints. For them, more simply, failure and disappointment can be seen more in material terms. An important element here was the lack of clinical material. Beyond this, the research-minded doctors, notably the German professors, came into conflict with a university system that seems in general not to have been adapted to the new research orientation emerging in Europe and the USA. There was no perceived linkage between the requirements of medical education on the one hand and the pursuit of medical knowledge on the other. The Dutch doctors who had spoken so strongly for

${ }^{105}$ H. H. Simmer, 'Principles and problems of medical undergraduate education in Germany during the nineteenth and early twentieth century', in C. D. O'Malley (editor), The history of medical education, UCLA Forum Medical Science no. 12, Los Angeles, University of California Press, 1970, pp. 173-200, see pp. 187ff.

106 Cf. S. S. Turner, 'The growth of professional research in Prussia, 1818 to 1848 - causes and context', Historical Studies in the Physical Sciences, 1971, 3: 137-182.

${ }^{107}$ Ibid; Ben-David, op. cit., note 2 above; Zloczower, op. cit., note 1 above. 


\section{Anja Hiddinga}

university training were, in fact, likely to be judged in terms of their capacities as healers on the one hand and by their educational efforts (including the writing of textbooks) on the other.

It is important to stress that there was no atmosphere in the Dutch universities resembling the "research imperative" that had developed in those of Germany, and which so strongly emphasized the production of original research. There was no need to write a research-based dissertation in order to obtain an academic post, nor was there the possibility of making a reputation based on research achievements. These stimuli were lacking. The possibility of a research career has been put forward as an important precondition for the beginning of research, ${ }^{108}$ and the absence of any institutional encouragement must have been a major inhibition in Holland.

Third, and strongly related to this, was the passive, laissez-faire attitude of the state, and the lack of any governmental stimulation. This was in marked contrast to Germany. ${ }^{109}$ Laboratories in Holland were small and badly equipped, and resources were not easy to acquire. There was no recognition of the need to provide resources, nor the need to stimulate new fields of science.

Fourth, according to some authors, ${ }^{110}$ competition was an important factor in the development of German medical science. This competition was essentially lacking in Holland, despite the discussions between the Leiden (Treub) and Amsterdam (Van der Mey) professors about the "international" character of their respective clinics. Treub refers here to his contacts with gynaecologists in Paris, while Van der Mey refers to the variety of nationalities among his patients. ${ }^{111}$ Although Treub was proud of his role in the Third International Congress on Gynaecology and Obstetrics, this was, in fact, due less to his research output than to his personality, his ability to speak foreign languages, and the wide scope of his foreign contacts. It was the result of the state of mind that still existed which promoted group feeling rather than competitiveness. This, together with the fact that research reputations were simply not to be made in Holland, is clearly a major explanatory factor.

Finally, the particular atmosphere of the Dutch obstetrical community contributed to the lack of research. This seems to be a necessary independent factor: there is no obvious reason why small groups of scientists in friendly contact with one another should not produce high-quality research. The contrast with the physical sciences is, after all, striking, for they too suffered from the same lack of resources and career opportunities and from state indifference. Even the lack of clinical material is insufficient to give a satisfying explanation. What seems crucial here is that despite the

108 A. Flexner, Medical education in Europe, New York, Carnegie Foundation, Bulletin no. 6, 1912; Ben David, op. cit., note 1 above; Zloczower, op. cit., note 1 above. This point is also made in the introduction to G. Lemaine et al., Perspectives on the emergence of scientific disciplines, The Hague and Paris, Mouton, 1976, 'Problems in the emergence of new disciplines', p. 7.

${ }_{109} \mathrm{Cf}$. Turner, op. cit., note 106 above; and Zloczower, op. cit., note 1 above.

110 Ben-David, op. cit., note 1 above; Zloczower, op. cit., note 1 above.

111 See Kouwer, op. cit., note 76 above, p. 5. Another illustration of this is the fact that Treub, who wrote a regular colum in NTG on the "social" aspects of medical life, saw his report of the congress of the Société Obstétricale in Paris in 1898 refused by the journal, because it dealt so much with the outside features of the congress (the garden party with the President of the Republic, the evening festivities in the Luxembourg, and Paris itself) that the editors thought it unsuited for the column. (J. A. van Dongen, Hector Treub I augustus 1856-7 april 1920. Zijn Persoon en Zijn Arbeid, Amsterdam, Scheltema en Holkema, 1965, p. 56.) 
ideas of "clinical science" that had been picked up, the Dutch university doctors did not see themselves as scientists, but rather as broadly oriented, all-knowing, classically-schooled and high-status members of society. Any explanation of the slow development of Dutch obstetric research in the nineteenth century must clearly be composed of a variety of interrelated elements: professional and political ideologies (the latter restricting the role of the state), themselves understandable in socio-cultural terms, and the manifestations of all this in the relevant institutions of Dutch society.

\section{ACKNOWLEDGEMENTS}

I am indebted to Stuart Blume and Olga Amsterdamska for their valuable comments on a previous draft of this paper. 